\title{
Sistem Alarm Pendeteksi Posisi Ternak Berbasis GPS dan SMS
}

\author{
Asmawaty Azis \\ Jurusan Teknik Elektro, \\ Fakultas Teknik, \\ Universitas Fajar \\ asmarudhy@gmail.com
}

\author{
Muh. Sakir \\ Jurusan Teknik Elektro, \\ Fakultas Teknik, \\ Universitas Fajar \\ haruna.sakir1007@gmail.com
}

\author{
Nurhalisa \\ Jurusan Teknik Elektro, \\ Fakultas Teknik, \\ Universitas Fajar \\ nurhalisa1209@gmail.com
}

\begin{abstract}
Breeders pen or place cattle in the field or outdoors without safety equipment. With conditions like this, it is undeniable that if there is a cattle theft and it will cause great losses to the cattle owners, a solution to overcome this problem is to create a GPS and SMS based cattle position detection alarm system. Cattle detection system (cow collar) uses arduino mega, 800L sim module and GPS. By testing the alarm system using four conditions, namely cattle leaving a safe position in the north, south, east and west, the system manages to provide information (alarm sounds) on these four conditions with . Meanwhile, the Livestock Detection System (SMS) was tested in four situations, namely when the cattle left a safe place at a distance of 10 meters, 30 meters, 50 meters, and 100 meters. Out of the five tests, the cattle detection system successfully sent information (sms) to the cattle owner's smartphone containing a Google map link for the position of the cattle at that distance.
\end{abstract}

Keyword: Livestock, GPS, Arduino mega, detection system, SIM 800L.

\section{PENDAHULUAN}

Indonesia merupakan negara yang kaya akan tumbuh-tumbuhan dan hewan yang dapat ditemui dengan mudah, tak heran jika berternak merupakan pekerjaan yang banyak digeluti oleh Masyarakat Indonesia. Salah satu hewan yang sering diternakkan adalah sapi. Sapi dapat mendatangkan keuntungan sangat besar bagi masyarakat dan dapat menjadi devisa bagi negara.

Para peternak membuatkan kandang atau menempatkan hewan ternak pada lapangan atau ditempat terbuka tanpa adanya alat pengaman. Dengan kondisi seperti ini tidak dipungkiri jika terjadi pencurian ternak dan itu akan menimbulkan kerugian yang besar bagi pemilik pihak ternak tersebut, sehingga untuk mencegah terjadinya pencurian pada para peternak akan mengawasi hewan ternaknya secara langsung.

Pengawasan secara langsung untuk ternak yang tidak banyak mungkin masih terasa ringan, tetapi mengawasi ternak dengan jumlah yang cukup banyak akan membuat para peternak kewalahan. Belum lagi pada malam hari para peternak akan terus menjaga untuk mengawasi ternak-ternaknya dan ini sangat tidak efisien.
Pada penelitian sebelumnya telah dikembangkan sebuah alat Monitoring pergerakan Hewan Ternak Menggunakan Teknologi Rfid, alat ini dipasang pada kandang sapi dan akan mendeteksi jika ada sapi yang keluar dari kandang. Alat ini hanya menginformasikan bahwa sapi telah keluar dari kandang. Tidak dilengkapi dengan GPS sehingga jika sipemilik ternak terlambat melakukan tindakan, maka posisi sapi tidak diketahui pada saat itu.

Berdasarkan uraian diatas maka akan dibuat sebuah sistem alarm pendeteksi posisi ternak berbasis GPS dan SMS. Alat ini didesain menjadi sebuah kalung yang akan dipasangkan pada leher sapi tersebut. Sistem deteksi ini menggunakan modul sim 808 yang telah dilengkapi dengan GPS dan SMS. Sistem akan bekerja jika sapi keluar dari titik koordinat yang telah ditentukan. Setelah itu sistem akan mengirimkan sebuah pesan singkat melalui via SMS yang berisi sebuah link google Maps pada smartphone sipemilik ternak mengenai posisi ternaknya pada saat itu. Alat ini menjadi salah satu solusi untuk lebih meminimalkan pengawasan dan mengoptimalkan sistem keamanan. Hal ini tentu saja akan mempermudah tugas seorang pengawas ternak serta mengurangi resiko pencurian terhadap hewan ternak tersebut. Berdasarkan uraian diatas maka saya melakukan penelitian yang berjudul "Sistem Alarm Pendeteksi Posisi Ternak Berbasis GPS dan SMS.

\section{TEORI DASAR}

Usaha penggemukan sapi merupakan kegiatan dengan menggerakan tenaga dan pikiran atau badan untuk mencapai sesuatu. Ternak merupakan sekumpulan hewan yang dipelihara dan dibudidayakan oleh manusia untuk mengambil hasil dari penaikan bobot sapi secara baik dan paling menguntungkan. Dengan demikian persiapan usaha yang sebaiknya dilakukan yaitu segala sesuatu yang dapat membantu dan mendukung dalam percepatan penggemukan sapi.seperti adanya usaha bersama mengenai tujuan sapi, sepeti adanya usaha bersama mengenai tujuan sapi yang dilakukan secara terpadu dan mandiri untuk memenuhi kebutuhan hidupnya agar kesehjahteraan dalam masyarakat dapat terwujud. Sistem deteksi posisi dapat juga disebut dengan sistem 
Locaton Based Service (LBS), ada dua definisi yang bisa menjelaskan tentang Location Based Service (LBS). Definisi Pertama: LBS adalah layanan informasi yang dapat diakses menggunakan piranti mobile melalui jaringan Internet dan seluler serta memanfaatkan kemampuan penunjuk lokasi pada piranti mobile [1].

GPS atau Sistem Pemosisi Global, adalah Unruk menentukan letak di permukaan bumi dengan bantuan penyelarasan siyal satelit. Sitem ini menggunakan 24 satelit yang mengirimkan sinyal gelombang mikro ke bumi. Layanan GPS ini tersedia gratis, bahkan tidak perlu mengeluarkan biaya apapun kecuali membeli GPS recierver-nya.

Short Message Service (SMS) adalah sebuah layanan yang dilaksanakan dengan sebuah ponsel untuk mengirim atau menerima pesan-pesan pendek.SMS pertama kali muncul di belahan Eropa pada tahun 1991 bersama sebuah teknologi komunikasi wireless yang saat ini cukup banyak penggunanya, yaitu GSM (Global Sistem for Mobile Communication) [2].

Mikrokontroler adalah suatu chip berupa IC (Integrated Circuit) yang dapat menerima sinyal input, mengelolahnya dan memberikan sinyal output sesuai dengan program yang diisikan ke dalamnya. Sinyal input mikrokontroler berasal dari sensor yang merupakan informasi dari lingkungan sedangkan sinyal output ditujukan kepada aktuator yang dapat memberikan efek ke lingkungan. Jadi secara sederhana mikrokontroler dapat diibaratkan sebagai otak dari suatu perangkat/produk yang mempu berinteraksi dengan lingkungan sekitarnya.

Arduino Mega 2560 Arduino adalah sebuah kit atau papan elektronik yang dilengkapi dengan software open source yang menggunakan keluarga mikrokontroler ATMega dan berfungsi sebagai pengendali mikro single-board yang dirancang untuk memudahkan penggunaan elektronik dalam berbagai bidang yang dirilis oleh Atmel. Dimana Hardwarenya memiliki prosesor Atmel AVR dan softwarenya memiliki bahasa pemrograman sendiri [3].

Alarm dapat didefinisikan sebagai bunyi peringatan dan pemberitahuan. Dalam istilah jaringan, alarm juga didefinisikan sebagai pesan berisi informasi atau pemberitahuan ketika terjadi penurunan atau kegagalan dalam penyampaian sinyal komunikasi data ataupun ada peralatan yang mengalami kerusakan (penurunan kinerja).

Baterai adalah perangkat yang terdiri satu atau lebih sel elektrokimia dengan koneksi eksternal untuk memberi daya pada perangkat listrik seperti senter, dan mobil listrik.

Arduino merupakan physical computing yang bersifat open source. Arduino tidak hanya sekedar sebuah alat pengembangan, tetapi ia adalah kombinasi dari hardware, bahasa pemrograman dan Integrated Development Environment (IDE) yang canggih. IDE adalah sebuah software yang sangat berperan untuk menulis program dalam memori microkontroller
Arduino Nano adalah salah satu papan mikrokontroler yang berukuran kecil, lengkap dalam penggunaan breadboard [4]

Modul SIM808 adalah modul GSM dan modul GPS yang digabungkan menjadi satu. Modul SIM808 mendukung jaringan Quad-Band dan menggabungkan teknologi GPS untuk navigasi satelit [5].

GPS Neo 6M adalah penerima sinyal GPS standalone yang memiliki performa baik. Time to First Fix (TIFF) adalah salah satu parameter penting dimana didefenisikan sebagai kecepatan modul GPS untuk dapat mengakses data almanac dan emepheris dari satelit. TIFF, dan neo-6M ini memiliki TIFF paling lama 27 detik [6].

SIM800L adalah sebagai modul GSM yang akan mengaktifkan prabayar sehingga dapat menerima sms. AT-Command yang digunakan pada SIM800L mirip dengan AT-Command untuk modul-modul GSM lain [7].

Elco dapat didefinisikan dalam suatu rangkaian elektronika yang di pakai untuk mengetahui nilai kapasitas sebuah elco didalam satuan uf (mikro farad). Fungsi elco biasanya di sebut sebagai kapasitor polar.

Step down sangat berguna untuk menurunkan tegangan pada listrik sehingga mendapatkan taraf yang paling sesuai dengan kebutuhan dari karakter peralatan penghantarnya.

\section{METODE PENELITIAN}

Dimulai dengan meyambungkan alat uji ke sumber tegangan yang akan diukur, Sistem deteksi ini menggunakan modul sim 800L. Sistem akan bekerja ketika sapi keluar dari titik koordinat yang telah ditentukan, maka disaat yang bersamaan sistem akan mengirim informasi berupa SMS kepada modul alarm untuk mengaktifkan alarm, kemudian mengirim SMS yang berupa link Google maps yang berisi sebuah informasi tentang posisi ternaknya pada saat itu.

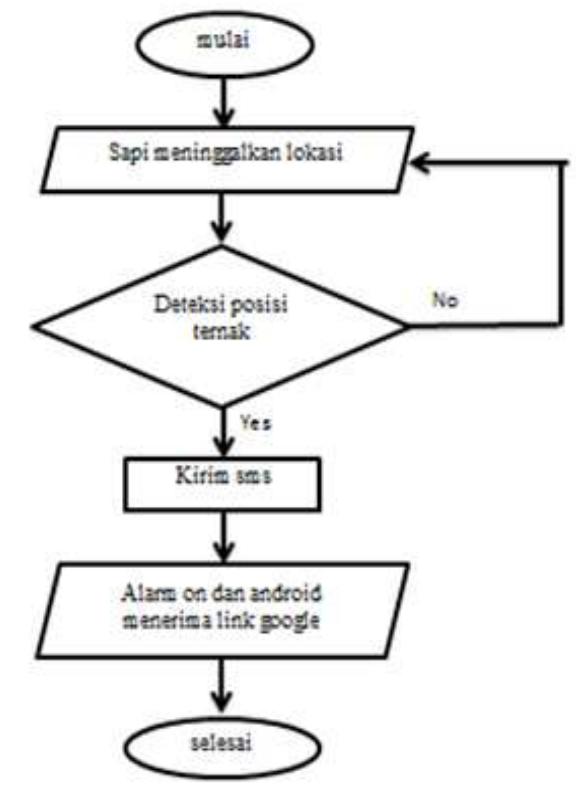

Gambar 1. Rancangan Sistem 
Berikut merupakan gambaran secara utuh tentang sistem alarm pendeteksi posisi ternak berbasis GPS dan SMS sistem yang akan dibuat.

Pada gambar 1. Alur Sistem ini akan mengaktifkan alarm jika ternak keluar dari titik koordinat yang telah ditentukan sebagai lokasi keamanan ternak, secara bersamaan sistem juga mengirim link google maps kepada smartphone pemilik ternak yang berisi titik koordinat lokasi ternak pada saat itu dengan menggunakan jaringan seluler GSM.

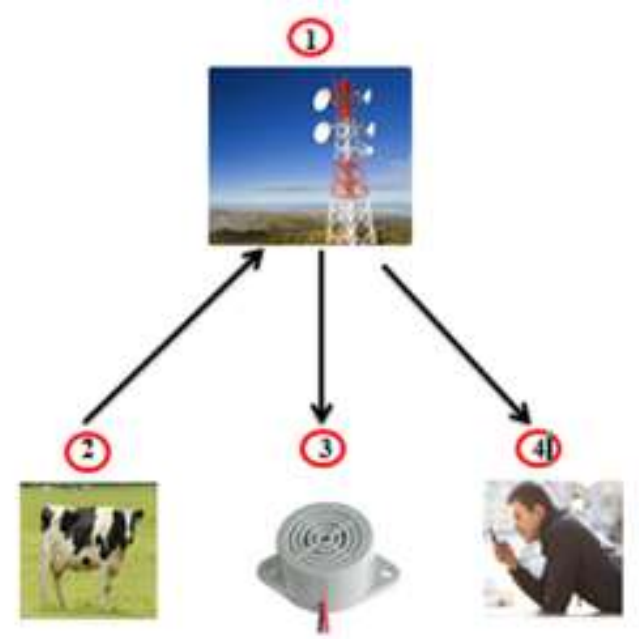

Gambar 2. Rancangan Alur Sistem

Keterangan Alur Gambar Pada Rancangan Desain Alat (Alarm) :

1. Elco ( Electronic Capasitor ) : Sebagai stabilizer tegangan yang masuk pada sim $800 \mathrm{~L}$.

2. Arduino nano : Sebagai controller untuk memproses data yang dikirim oleh sim 800L.

3. Sim 800L : Sebagai modul GSM yang akan mengaktifkan kartu prabayar sehingga dapat menerima SMS dan mengirimkannya ke Arduino.
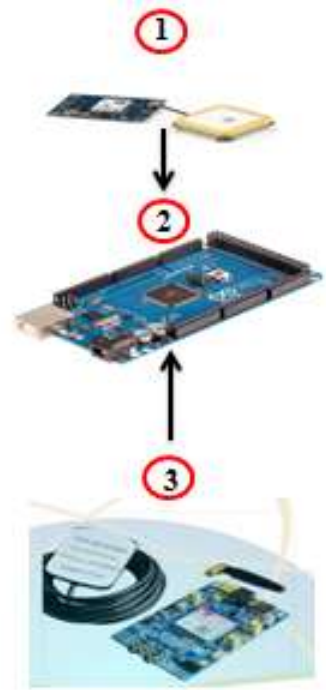

Gambar 3. Rancangan Desain Alat Deteksi
Keterangan Alur pada Gambar diatas :
1. Tower : Penangkap jaringan.
2. Sapi : Posisi sapi berada dilapangan.
3. Buzzer : Memberikan tanda ketika ternak keluar dari Lapangan.
4. Smartphone: Penerima Notifikasi.

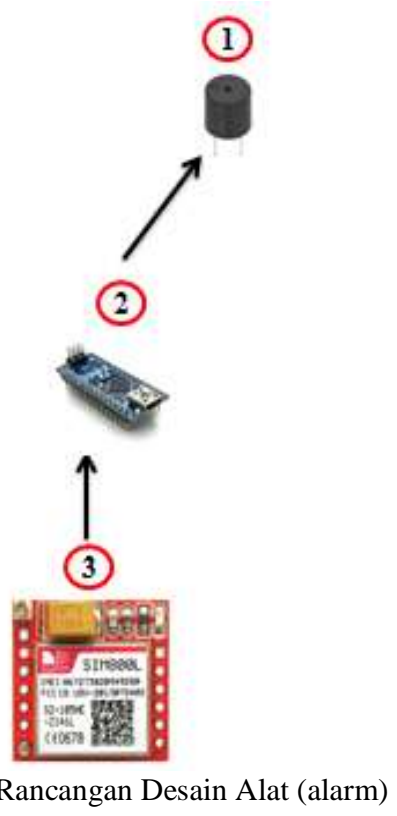

Keterangan Alur Gambar Pada Rancangan Desain Alat ( Ternak ) :

1. GPS NEO 6M: Untuk membaca titik koordinat

2. Arduino mega: Sebagai controller untuk memproses data yang dikirim oleh sim 800L.

3. Sim 808 : Sebagai modul GSM yang akan mengaktifkan kartu prabayar sehingga dapat menerima SMS dan mengirimkannya ke Arduino.

Pada gambar diatas Alur sistem pada Alarm dan ternak yaitu sistem ini akan mengaktifkan alarm ketika ternaknya keluar dari titik koordinat yang telah ditentukan atau sebagai lokasi keamanan ternak, secara bersamaan sistem akan mengirimkan sms yang berupa link google maps kepada si smartphone pemilik ternak yang dimana keberadaan ternaknya pada saat itu .

Pada Gambar 3 dan Gambar 4 Arduino mega sebagai mikrokontroler yang mengatur alur kerja alat. Dari Arduino mega akan disalurkan 5 Volt ke setiap komponen. Selanjutnya, semua Pin I/O Digital, Pin Analog, dan Pin Power dari GPS Shield dihubungkan ke semua Pin I/O Digital, Pin Analog, dan Pin Power di Arduino Uno, ini karena GPS Shield Board sudah dirancang kompatibel dengan Arduino Uno Board, lalu kita set Software Serial GPS Shield Pin TX ke Pin 7 dan Pin RX ke Pin 8 untuk terhubung dan berkomunikasi dengan Pin Arduino mega. Begitupula untuk modul $800 \mathrm{~L}$ yang kompatibel dengan Arduino Uno Board, pin RX 
dihubungkan ke pin 5 dan pin TX dihubungkan ke pin 6 untuk terhubung dan berkomunikasi dengan Pin Arduino mega.

\section{HASIL DAN PEMBAHASAN}

Berikut ditampilkan hasil rancangan pada alat ternak

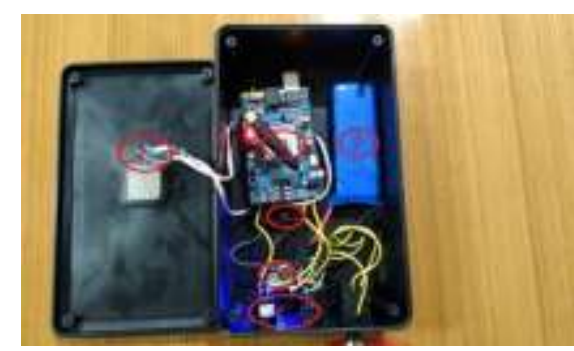

Gambar 5. Hasil Sistem Pendeteksi Ternak

Keterangan pada gambar diatas :

1. Arduino mega : Sebagai controller untuk memproses data yang dikirim oleh aim 808L.

2. SIM 808L : Sebagai modul GSM yang akan mengaktifkan kartu prabayar sehingga dapat menerima SMS dan mengirimkannya ke Arduino.

3. GPS NEO 6M : Untuk membaca titik koordinat.

4. Baterai : Untuk menyuplai

5. Stepdown : Untuk menurunkan tegangan baterai ke 5 volt

6. Pushbutton : Tombol power of/on

Pada gambar diatas Cara kerja alat pada ternak yaitu penelitian ini menggunakan GPS NEO 6M membaca titik koordinat setelah itu akan dikirim ke arduino mega melalui komunikasi serial dan arduino akan memproses data yang dikirmkan oleh GPS apabila titik koordinat yang terdeteksi berada diluar area yang telah ditentukan, maka alat akan mengirimkan sms melalui modul sim 800L sebanyak satu kali kepada smarphonen kepimilik ternak dan juga akan mengaktifkan alarm yang ada pada kandang.

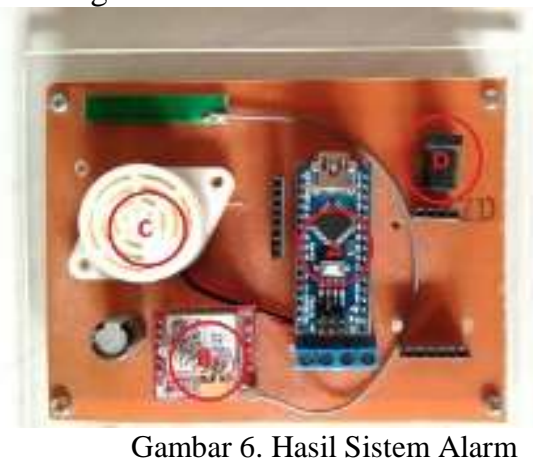

Keterangan pada gambar diatas :

1. Arduino nano : Sebagai controller untuk memproses data yang dikirim oleh aim 808L.

2. Sim 800L : Sebagai modul GSM yang akan mengaktifkan kartu prabayar sehingga dapat menerima SMS dan mengirimkannya ke Arduino.
3. Buzzer : sebagai output yang dapat merubah energy listrik menjadi suara.

4. Elco ( electronict capasitor ) : Sebagai stabilizer tegangan yang masuk pada $\operatorname{sim} 800 \mathrm{~L}$.

Pada gambar diatas cara kerja alat pada Alarm yaitu penelitian ini menggunakan Arduino sebagai mikrokontroler dan sim800L sebagai modul GSM, ketika sim 800L menerima sms dari alat pada ternak maka alarm akan berbunyi sampai ternak kembali masuk ke area yang telah ditentukan atau pemilik ternak bisa mematikan alarm secara langsung melalui sms.

Pengujian Sistem Alarm Pendeteksi Posisi Ternak Berbasis GPS dan SMS dapat memonitoring keadaan pada lapangan, dimana keadaan yang bisa di deteksi yaitu pada saat sapi keluar dari titk koordinat yang telah ditentukan.

Pada saat sapi meninggalkan lokasi keamananm ternak sistem yang terpasang pada leher sapi mengirimkan pesan pada sistem alarm yang terdapat pada lokasi keamanan ternak, sebagai tanda peringatan bahwa sapi meninggalkan lokasi aman.

Tabel 1. Pengujian Alarm

\begin{tabular}{|c|c|c|c|c|c|c|c|}
\hline \multirow{2}{*}{ No } & \multicolumn{2}{|c|}{ Alat } & \multicolumn{2}{|c|}{ Jarak } & \multicolumn{2}{|c|}{ Kecepatam } & \\
\hline & $\begin{array}{c}\text { Pengujian } \\
1\end{array}$ & $\begin{array}{c}\text { Pengujian } \\
2\end{array}$ & $\begin{array}{c}\text { Pengujian } \\
1\end{array}$ & $\begin{array}{c}\text { Pengujim } \\
2\end{array}$ & $\begin{array}{c}\text { Pengujian } \\
1\end{array}$ & $\begin{array}{c}\text { Pengujiam } \\
2\end{array}$ & \\
\hline 1. utara & berhasil & Berthasil & 10 meter & 10 meter & 2 menit & 10 menit & Sesuai \\
\hline 2.selatim & berhasil & Berhasil & 30 meter & 30 meter & 1 menit & 1 menit & Sesuai \\
\hline 3. timir & Berthasil & Berhasil & 50 meter & 50 meter & 2 menit & 7 menit & Sesuai \\
\hline 4. barrat & berthasil & Berthasil & 100 meter & 100 meter & 3 menit & 14 menit & Sesuai \\
\hline
\end{tabular}

Pada tabel 1 pengujian alarm dilakukan dengan empat titik yaitu ternak keluar dari posisi aman melalui arah utara, selatan, barat dan timur. Ketika ternak meninggalkan lokasi pada arah utara sistem alarm berhasil memberikan informasi (alarm berbunyi). Begitupun ketika ternak meninggalkan lokasi aman melalui arah selatan, barat dan timur sistem alarm berhasil memberikan informasi (alarm berbunyi) yang menandakan ternak keluar dari posisi aman.

Tabel 2. Pengujian Sistem Deteksi Ternak (SMS)

\begin{tabular}{|c|c|c|c|c|c|c|}
\hline \multirow[b]{2}{*}{ No } & \multirow[b]{2}{*}{ Jarak } & \multicolumn{2}{|c|}{ Sms } & \multicolumn{2}{|c|}{ Sms } & \multirow[b]{2}{*}{ Hasil } \\
\hline & & Percobasm 1 & Percobasm 2 & $\begin{array}{c}\text { Kecepstam } \\
1\end{array}$ & Kecepstan 2 & \\
\hline 1. & 10 meter & Berthasil & Berthasil & 2 menit & 1 menit & Sesuai \\
\hline 2. & 30 metter & Berthasil & Berhasil & 2 menit & 10 menit & Sesuai \\
\hline 3. & 50 meter. & Berthasil & Berthasil & 2 menit & 7 menit & Sesuai \\
\hline 4. & 100 meter & Bertasil & berhasil & 3 menit & 4 menit & Sesuai \\
\hline
\end{tabular}

Pada tabel 2 menunjukkan pengujian sistem deteksi ternak dilakukan diberbagai titik lokasi, menghasilkan keakuratan sistem. Ada lima titik lokasi yang diujikan yaitu jarak 10 meter, 30 meter, 50 meter, dan 100 meter. Dari kelima pengujian titik lokasi sistem berhasil mengirimkan SMS yang berisi 
link google maps yang memberikan informasi tentang keberadaan ternak.

Pada pengujian sistem SMS yang dengan berbagai titik lokasi mengahasilkan beberapa keakuratan dalam menerima data posisi. Pengujian yang dilakukan dalam jarak 10 meter,30 meter, 50 meter, dan 100 meter menghasilkan keakuratan penerimaan data yang sangat tinggi dimana menghasilkan 90\% kecepatan maksimal penerimaan data.

\section{KESIMPULAN}

Berdasarkan hasil penelitian yang telah dilakukan dapat ditarik kesimpulan yaitu sistem pendeteksi posisi ternak telah berhasil dirancang dan dibuat menggunakan arduino mega, sim 800L, buzzer, baterai, kartu sim telkomsel, step down, GPS NEO 6M. Sistem deteksi ternak (sms) diujikan dengan lima keadaan yaitu ketika ternak keluar dari lokasi aman pada jarak 10 meter, 30 meter, 50 meter, dan 100 meter. Dari kelima pengujian sistem deteksi ternak alat berhasil mengirimkan informasi (sms) pada smartphone pemilik ternak yang berisikan link google maps posisi ternak pada jarak tersebut. Pengujian sistem alarm menggunakan empat kondisi yaitu ternak meninggalkan posisi aman pada arah Utara, selatan, timur dan barat, sistem berhasil memberikan informasi (alarm berbunyi) pada keempat kondisi tersebut.

\section{DAFTAR PUSTAKA}

[1] Widodo, L. (2019). Rancang Bangun Sistem Deteksi Posisi Sapi berbasis Smartphone. 1-10.

[2] Ichsan, M. N. (2019). Rancang Bangun Sistem Pendeteksi Pencurian Ternak Sapi Berbasis Mikrokontroler (Studi Kasus di Kecamatan Bontonompo Kabupaten Gowa).

[3] Iskandar, A., Muhajirin, M., \& Lisah, L. (2017). Sistem Keamanan Pintu Berbasis Arduino Mega. Jurnal Informatika Upgris, 3(2), 99-104. https://doi.org/10.26877/jiu.v3i2.1803

[4] Fisika, D., Matematika, F., Ilmu, D. a N., Alam, P., \& Utara, U. S. (2016). Universitas Sumatera Utara - Beranda. 168, 4-16. https://www.usu.ac.id/id/

[5] Fadhurrahman, M. (2019). Rancang bangun sistem pelacak kendaraan bermotor menggunakan gps dan gsm berbasis arduino nano.

[6] Firdaus, F., \& Ismail, I. (2020). Komparasi Akurasi Global Posistion System (GPS) Receiver U-blox Neo-6M dan U-blox NeoM8N pada Navigasi Quadcopter. Elektron: Jurnal Ilmiah, 12(1), 12-15. https://doi.org/10.30630/eji.12.1.137

[7] Kafafi, R. F. (2019). Rancang Bangun Monitoring Suhu Dan. Mahasiswa Teknik Informatika, 3(2), 98-104. 